\title{
Serological Identification of Dasheen mosaic virus in Anthurium sp. in the State of Ceará
}

\author{
Roberto C. A. Lima1, J. Albersio A. Lima ${ }^{2 *}$ \& J. Rubens Aguiar ${ }^{3}$ \\ ${ }^{1}$ Setor de Fitossanidade, Secretária de Agricultura Irrigada do Ceará - SEAGRI, Fortaleza, CE, Brasil; ${ }^{2}$ Laboratório de Virologia \\ Vegetal, Universidade Federal do Ceará, Fortaleza, CE, Brasil, e-mail: albersio@ufc.br; ${ }^{3}$ Projeto Flores, Secretária de Agricultura \\ Irrigada do Ceará - SEAGRI, Fortaleza, CE, Brasil
}

(Accepted for publication on 12/12/2003)

Corresponding author: Roberto C. A. Lima

\begin{abstract}
RESUMO
Identificação sorológica de Dashim mosaic virus em Antúrio no estado do Ceará

Os antúrios (Anthurium spp.) são cultivados nas serras úmidas do estado do Ceará, especialmente, no Maciço de Baturité e vem despontando como promissora ornamental no mercado internacional. Plantas com sintomas de vírus foram constatadas em visitas de inspeção a plantios comerciais de antúrios no Maciço de

Baturité. Testes sorológicos de Elisa indireto com amostras de flores e de folhas de plantas com sintomas apresentaram resultados positivos para Dasheen mosaic virus, família Potyviridae, gênero Potyvirus. A constatação de inclusões citoplasmática em células da epiderme de plantas infetadas confirmou a infecção por vírus do gênero Potyvirus. Este é o primeiro registro da incidência do DMV no Ceará.
\end{abstract}

The production of tropical flowers under irrigation has become economically important in the State of Ceará, and the anthurium (Anthurium sp.) is becoming a promising ornamental for the external market. The Baturité region of Ceará has become an important center of ornamental tropical flower production due to its soil and climatic conditions. During inspections of commercial anthurium plantations in Guaramiranga County in the Baturité Mountains, a high incidence of plants was found to exhibit symptoms of mosaic, chlorotic strips along their foliar veins, which reduced plant development, and created bract distortions and color modifications in the flowers (Figure 1). More than $60 \%$ of the plants at the inspected anthurium plantations exhibited the above-described symptoms.

Leaf and flowers samples were collected from 20 symptomatic anthurium plants were collected and taken to the Plant Virus Laboratory at the Federal University of Ceará. All samples were tested by indirect enzyme linked immuneabsorbent assay (Elisa), against antisera specific for Dasheen mosaic virus (DMV), family Potyviridae, genus Potyvirus, and Cucumber mosaic virus (CMV), family Bromoviridae, genus Cucumovirus. The DMV-antiserum was kindly furnished by Dr. W. Zettler (University of Florida, USA) and the CMVantiserum was produced at the Plant Virus Laboratory, UFC. According to the Elisa test results, all the anthurium samples with symptoms of the virus reacted with the antiserum for DMV, absorption values at $405 \mathrm{~nm}$ three times above the absorption values for the samples from healthy plants. No reaction was detected with the antiserum for CMV. Cytoplasmic

*Bolsista do CNPq inclusions typical of virus from the Potyvirus genus were observed by light microscope in epidermal strips from infected plants, confirming the presence of a potyvirus. The DMV has a wide host range and its occurrence has been demonstrated in several ornamental and edible plants from the Araceae family. The virus is transmitted by aphid in a non persistent manner, by vegetative plant propagation, and by mechanical inoculation (Zettler et al. CMI/AAB Descriptions of Plant Viruses No. 191). The evolution of the virus infection causes color degradation in the flowers and bractless deformations, with a serious consequence in terms of the appearance and quality of the flowers (Figure 1). This is the first reference to the occurrence of DMV in Ceará. Considering the importance of DMV for anthurium production, control strategies are being taken in Ceará, with the goal to produce virus free nurseries, and to avoid virus dissemination by plant tissue propagation.

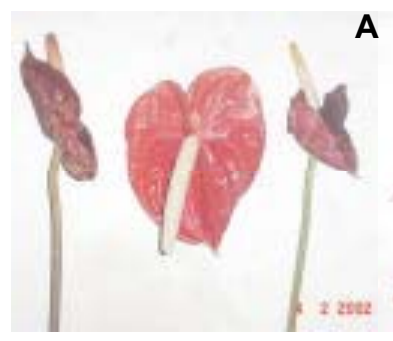

A

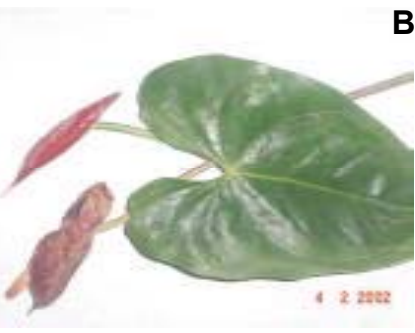

FIG. 1 - Flowers and leaves of anthurium (Athurium sp.) exhibiting symptoms of Dasheen mosaic virus. A) Flowers color modifications and bractless distortions; B) Leaf with mosaic and flowers with color modifications. 